\title{
Application of hormonal subdoses at acupoint Hou Hai in estrus synchronization protocols of goats
}

\section{Aplicação de subdoses hormonais no acuponto Hou Hai em protocolos de sincronização de estro em caprinos}

\author{
Reuber de Carvalho Cardoso ${ }^{1}$; Larissa Pires Barbosa ${ }^{2 *}$; Rosiléia Silva Souza ${ }^{3}$; \\ Caline Santana da França ${ }^{4}$; Manoel Diran Maia Ribeiro Junior ${ }^{5}$; Ana Lúcia \\ Almeida Santana ${ }^{6}$; Ronival Dias Lima de Jesus ${ }^{7}$; Rosimere Santana dos Santos ${ }^{5}$
}

\begin{abstract}
The objective was to evaluate the efficacy of hormonal subdoses at acupoint Hou Hai in estrus synchronization of goats. Sixty-nine females goats received intravaginal sponges containing $60 \mathrm{mg}$ of medroxyprogesterone acetate for seven days and were randomly distributed among three treatments: 11 ( $n=23$ ): application of $125 \mu \mathrm{g}$ of PGF2 $\alpha$ on the sixth day (D6) and $300 \mathrm{UI}$ of eCG on the seventh day (D7), both intramuscularly (IM); T2 ( $n=23)$ and T3 $(n=23)$ : application $37.5 \mu \mathrm{g}$ of PGF2 $\alpha$ at D6 and 90 UI of eCG at D7, applied by Hou Hai acupuncture and false acupuncture (IM), respectively. The goats were subjected to hormonal protocol and monitored for the coverage and evaluation of reproductive parameters. The data were subjected to normality analysis, followed by appropriate statistical tests for each variable. Greater numbers of estrus goats were obtained in treatments one $(\mathrm{T} 1=100 \%)$ and three $(\mathrm{T} 3=91.3 \%)(\mathrm{p}<0.05)$. No difference was observed $(\mathrm{p}>0.05)$ for sponge removal intervals at the beginning $(35.9 \mathrm{~h})$ and end $(59.8 \mathrm{~h})$ of estrus, and for the duration of estrus $(24.7 \mathrm{~h})$, gestation rate at 30 (77\%) and 60 (76.7\%) days, and prolificacy (1.9). The use of PGF2 $\alpha$ and eCG in subdoses applied to the Hou Hai acupoint or false acupoint was efficient in synchronizing estrus in goats, based on the rate of gestation and prolificity of the animals.
\end{abstract}

Key words: Pharmacopuncture. Hormone. Small ruminants.

\section{Resumo}

\begin{abstract}
Objetivou-se avaliar a eficácia de subdoses hormonais no acuponto Hou Hai na sincronização de estro em cabras. Sessenta e nove fêmeas receberam esponjas intravaginais com $60 \mathrm{mg}$ de acetato de medroxiprogesterona por sete dias, e distribuídas aleatoriamente em três tratamentos: T1 $(n=23)$ : aplicação de $125 \mu \mathrm{g}$ de PGF2 $\alpha$ no sexto dia (D6) e 300UI de eCG no sétimo dia (D7), ambos por via intramuscular (IM); T2 $(n=23)$ e T3 $(n=23)$ : receberam 37,5 $\mu$ g de PGF2 $\alpha$ no D6 e 90UI de eCG no D7, aplicados no acuponto Hou Hai e em falso acuponto (IM), respectivamente. As cabras foram submetidas ao protocolo hormonal e monitoradas para realização das coberturas e avaliação

\footnotetext{
${ }^{1}$ M.e, Universidade Federal do Recôncavo da Bahia, UFRB, Cruz das Almas, BA, Brasil. E-mail: reubercarv@gmail.com

2 Prof ${ }^{a}$, UFRB, Cruz das Almas, BA, Brasil. E-mail: larissa@ufrb.edu.br

Dor ${ }^{\text {a }}$, Universidade Federal da Bahia, UFBA, Salvador, BA, Brasil. E-mail: rosileiasouza@hotmail.com

4 Discente de Mestrado, UFRB, Cruz das Almas, BA, Brasil. E-mail: francacs@outlook.com

5 Médico Veterinário, UFRB, Cruz das Almas, BA, Brasil. E-mail: m.diran@hotmail.com

6 Pesquisador, UFRB, Cruz das Almas, BA, Brasil. E-mail: zootecana@gmail.com

7 Discente, UFRB, Cruz das Almas, BA, Brasil. E-mail: ronydias_19@hotmail.com

* Author for correspondence
} 
de parâmetros reprodutivos. Os dados foram submetidos à análise de normalidade, seguido dos testes estatísticos adequados para cada variável. Obteve-se maior número de cabras em estro nos tratamentos um $(\mathrm{T} 1=100 \%)$ e três $(\mathrm{T} 3=91,3 \%)(\mathrm{p}<0,05)$. Não houve diferença $(\mathrm{p}>0,05)$ para os intervalos da retirada da esponja ao início $(35,9 \mathrm{~h})$ e final $(59,8 \mathrm{~h})$ do estro, bem como para a duração do estro $(24,7 \mathrm{~h})$, taxa de gestação aos $30(77 \%)$ e $60(76,7 \%)$ dias, e prolificidade $(1,9)$. O uso de subdoses de $\mathrm{PGF}_{2} \alpha$ e de eCG aplicados no acuponto Hou Hai ou em falso acuponto foram eficientes na sincronização de estro em caprinos, com base na taxa de gestação e prolificidade dos animais.

Palavras-chave: Farmacopuntura. Hormônio. Pequenos ruminantes.

\section{Introduction}

The use of hormones to control the estrous cycle in goats has been shown in several studies, as a method that enhances the production efficiency of the herd, an increases the animals born per year, reduction of the service period and calving interval, and improvement in production system organization. The most common protocols of estrus synchronization for this species employ a combination of Progestin, Prostaglandin F2 $\alpha$ (PGF2 $\alpha$ ), and Equine Chorionic Gonadotropin (eCG) (MAIA; BEZERRA, 2010).

However, this biotechnology is not available to most producers, due in part to the cost of hormonal protocols in relation to the market value of the animal. Thus, some hormonal protocols use pharmacopuncture, with the objective of reducing the hormone doses of the hormones used and consequently the cost, with at least the same level of efficiency as that of conventional protocols (SIMPLÍCIO, 2008).

Pharmacopuncture is based on the application of substances at low doses at acupoints while maintaining or increasing the potency of action and reducing the undesirable side effects of drug residues in animal products, with advantages in practicality and efficacy of the treatment (ALTMAN, 2006). In the reproductive system, this method has applications in the treatment of various conditions such as anestrus, ovarian cysts, persistent corpus luteum, and repetition of estrus, among others (CHAN et al., 2001), and is also associated with estrus synchronization protocols (MAIA; BEZERRA, 2010).
Among the acupoints acting on the reproductive system, the Hou Hai, also known as Governing Vessel 1 (VG1), located in the depression between the mean distance ventral base of the tail and the anus, has been reported to be used in the treatment of reproductive disorders (LIN et al., 2006) and control of the estrus cycle; it has been proven to induce estrus in cows only with the encouragement of needling (KOMATSU et al., 1998) and also in sheep by the method of pharmacopuncture (QUICK, 2010).

Thus, the study aimed to evaluate the effectiveness of the applying of PGF2 $\alpha$ and eCG subdoses at acupoint Hou Hai in goat estrus synchronization protocols.

\section{Material and Methods}

\section{Experiment location}

The study was conducted in the goat breeding sector at the Federal University of Bahia Reconcavo (UFRB), located in Cruz das Almas, Bahia, the $12^{\circ} 39^{\prime} 54.9^{\prime \prime}$ South Latitude, 3904'36.9' West Longitude, and an altitude of $195 \mathrm{~m}$ above sea level (GPS Garmin, eTrex ${ }^{\mathrm{TM}} 30$ ), which features hot humid tropical climate. The mean temperature and humidity during the experimental period was $27^{\circ} \mathrm{C}$ and $71.5 \%$, respectively.

\section{Animals}

Sixty-nine crossbred goats of the Alpine and Anglonubian races with a mean age of $2.75 \pm 0.1$ years, otherwise healthy, non-lactating, pluriparous, 
and with an average body condition score (BCS) of $2.25 \pm 0.2$ were selected by means of clinical and gynecological examination by transrectal ultrasound assistance (Pie Medical, ÀquilaVet model, linear transducer $6 \mathrm{MHz}$ ). The animals were kept on a semi-intensive regime of creation on pasture Aruana (Panicum maximum cv. 'Aruana') with concentrated supplementation once a day; and mineral mixture and water were provided $a d$ libitum.

\section{Hormonal protocol and experimental distribution}

All goats received polyurethane intravaginal sponges impregnated with $60 \mathrm{mg}$ medroxyprogesterone acetate (MAP) (Progespon ${ }^{\mathrm{TM}}$, Syntex SA, Buenos Aires, Argentina), and $0.1 \mathrm{mg}$ oxytetracycline (Tetrabac LA ${ }^{\mathrm{TM}}$, Bayer SA, Northern Ireland) for a period of seven days. The animals were randomly assigned into three treatments: T1 ( $\mathrm{n}=23$ ) (traditional protocol with $100 \%$ of the dose of PGF2 $\boldsymbol{\alpha}$ and eCG): $125 \mu \mathrm{g}$ applying a synthetic analogue of PGF2 $\boldsymbol{\alpha}$ (Cloprostenol Sodium - Ciosin ${ }^{\mathrm{TM}}$, Coopers, São Paulo, Brazil) on the sixth day (D6) and 300 international units (IU) of eCG (Novormon, Coopers $^{\mathrm{TM}}$, São Paulo, Brazil) on D7, both applied intramuscularly (IM); T2 (n=23) and T3 $(n=23)$ (Protocols with $30 \%$ of the dose of PGF2 $\boldsymbol{\alpha}$ and eCG): administration of $37.5 \mu \mathrm{g}$ PGF $2 \boldsymbol{\alpha}$ and 90 IU eCG D6 and D7, both applied to acupoint Hou Hai and a false acupoint (IM), respectively for $\mathrm{T} 2$ and $\mathrm{T} 3$.

For the false acupoint (T3), intramuscular (IM) administration was performed in the semitendinosus muscle of the pelvic limbs.

\section{Pharmacopuncture protocol}

Applications of hormones at acupoint Hou Hai was carried out using hypodermic needles $\left(\mathrm{BD}^{\mathrm{TM}}\right)$ gauge $21 \mathrm{G} \mathrm{11/4}$ inches, $0.80 \times 30 \mathrm{~mm}$ long. The needle insertion angle was $90^{\circ}$, perpendicular to the insertion point, and the depth was $3 \mathrm{~cm}$, adapted from the technique used in dogs (HWANG; LIMEHOUSE, 2006). Sites were disinfected using povidone-iodine (Polyvinylpyrrolidone) before application.

\section{Valuated variables and breeding season}

This study evaluated the number and percentage of animals in estrus (AE) (\%), the interval between sponge removal to estrus onset (SRIOE), interval between sponge removal at the end of estrus (SRIEE), duration of estrus (ED), gestation rate at 30 and 60 days, and prolificacy.

After the withdrawal of sponges at D7, the animals were monitored for estrous behavior and mating with mounts controlled at $12 \mathrm{~h}$ intervals, using players with proven fertility, at a ratio of eight females to one male (8:1). Estrus onset was considered as the time when the female began to accept the male mounts whereas mounts rejection behavior was considered as the end of estrus. The duration of estrus was determined by calculated the difference between the end and beginning of estrus.

The diagnosis of gestation was performed by transrectal ultrasonography using an ultrasound device (Pie Medical, ÀquilaVet model) connected to a linear transducer at a frequency of $6 \mathrm{MHz}$. Fetal presence and the presence of heartbeats were used as indicators of gestation and viability, respectively. The ultrasounds were performed at D30 and D60 of gestation, to determine the gestation rate (GR\%) and after birth, prolificacy was determined by dividing the number of live births or killed by the number of deliveries.

\section{Statistical analysis}

Data were assessed for normality using the Shapiro-Wilk test. The analysis of quantitative variables with normal distribution was performed by ANOVA and Tukey's test at 5\% significance level. For variables without normal behavior we 
used the Kruskal-Wallis test. The non-parametric Chi-square test $\left(X^{2}\right)$ was adopted for the binomial qualitative variables with a 5\% significance level. SPSS version 21 was used for the statistical analyses (1989-2012).

\section{Results and Discussion}

There were differences in the percentage of animals in estrus $(p<0.05)$, presenting $100 \%$ of estrus in animals from $\mathrm{T} 1$, and $74 \%$, and $91.3 \%$ from $\mathrm{T} 2$ and $\mathrm{T} 3$, respectively, where $\mathrm{T} 1$ and $\mathrm{T} 3$ showed mean equivalent estrus, whereas T2 achieved a lower percentage of estrus in animals (Table 1). Maffili et al. (2006) tested the effectiveness of short protocols to induce estrus goats, consisting of 60 $\mathrm{mg}$ of MAP and added to PGF2 $\boldsymbol{\alpha}$ and eCG, and $50 \mu \mathrm{g}$ PGF2 $\boldsymbol{\alpha}$ and $250 \mathrm{IU}$ eCG, and demonstrated $100 \%$ estrus rates.

Table 1. Estrus behavior in goats subjected to synchronization protocols associated with the hormonal acupoint application on Hou Hai.

\begin{tabular}{|c|c|c|c|c|}
\hline Variables & T1 & T2 & T3 & Mean \\
\hline $\operatorname{AE~}(\%)^{2}$ & $100(23 / 23) a$ & $74(17 / 23) b$ & $91.3(21 / 23) \mathrm{a}$ & $88.43(61 / 69)$ \\
\hline SRIOE (h) ${ }^{1}$ & $35.18 \pm 12$ & $36.05 \pm 39$ & $37.40 \pm 17.76$ & $35.90 \pm 14.37$ \\
\hline SRIEE $(h)^{2}$ & $59.06 \pm 9.92$ & $53.41 \pm 34.75$ & $67.24 \pm 21.0$ & $59.80 \pm 24.48$ \\
\hline ED (h) ${ }^{1}$ & $24.43 \pm 13.83$ & $24.47 \pm 35.92$ & $33.89 \pm 14.17$ & $24.71 \pm 13.68$ \\
\hline
\end{tabular}

T1 - Treatment 1 (100\% IM); T2 - Treatment 2 (30\% acupoint Hou Hai); T3 - Treatment 3 (30\% false acupoint). AE (\%) - Animals in estrus; There was a statistically significant difference $(\mathrm{p}<0.05)$. SRIOE - sponge removal interval to onset of estrus in hours; SRIEE - sponge removal interval at the end of estrus in hours; ED - estrus duration in hours. ${ }^{1}$ Non-parametric data (median \pm interquartile). ${ }^{2}$ Parametric data (mean $\pm \mathrm{SD}$ ). Different letters in the line differ from each other by the Tukey test at $5 \%$ significance.

Although there was a difference in the percentage of estrus animals (Table 1), all protocols were considered effective for inducing estrus. Leite et al. (2006) reported that a $66.6 \%$ estrus rate is considered satisfactory for goats. Fonseca et al. (2003) reports that the estrus induction response in goats can vary from $60 \%$ to $100 \%$, based on the individual and environmental factors, animal health, and nutrition.

It can be deduced that the reduced hormone doses (37.5 $\mu$ g of PGF2 $\alpha$ and eCG 90 IU) used for $\mathrm{T} 2$ and $\mathrm{T} 3$ were sufficient to trigger responses in the hypothalamic-pituitary-gonadal axis, with probable regression of the present corpora lutea present in stimulating the release of gonadotropins (FSH and LH) and follicle steroidogenesis at physiological levels in goats.

Paulus et al. (2002) and Chang et al. (2002) used acupuncture application, and proposed the function of the regulatory mechanism of the hypothalamicpituitary-ovarian axis via the central sympathetic system. This model is based on high concentrations of $\beta$ endorphin in the cerebrospinal fluid promoting central sympathetic inhibition, thereby resulting in temporary suppression of GnRH pulses and peripheral levels of gonadotropins, with return in the release of these hormones after stimulation ceases at the acupoint and a corresponding reduction in the levels of $\beta$ endorphin.

Possibly, this mechanism was not triggered in animals that showed no estrus in $\mathrm{T} 2$, which received reduced hormone doses at the acupoint Hou Hai. It is therefore suggested that in estrus goats, needling and the volume of the injected content at the acupoint provided sufficient physical stimulation to increase $\beta$ endorphin with a temporary suppression of GnRH, and the physiological LH pulses returned when the local effect at the acupoint was ceased; 
this is also associated with the application of eCG (90 IU).

Other reproductive performance parameters did not differ between groups $(p>0.05)$. The interval from sponge removal to onset of estrus (SRIOE) was $35.90 \pm 14.37 \mathrm{~h}$ for all treatments. The mean interval from sponge removal to the end of estrus (SRIEE) was $59.80 \pm 24.48 \mathrm{~h}$. The duration of estrus (ED) was similar between groups occurring at an average of $24.71 \pm 13.68 \mathrm{~h}$ (Table 1).

In goats estrus can start in the range of $12-48$ hours after withdrawal of the progesterone source (TRALDI et al., 2007). In addition, based on the results of other studies, the range for estrus onset averages $40.65 \pm 3.27 \mathrm{~h}$ ( $250 \mathrm{IU}$ eCG), $32.54 \pm 3.00$ h (500 IU of eCG) (NAVA-TRUJILLO et al., 2010), and $31.53 \pm 2.81 \mathrm{~h}(250 \mathrm{IU}$ eCG) (MAIA JÚNIOR et al., 2009). Thus, in this study $(35.90 \pm 14.37 \mathrm{~h})$ the manifestation of estrus was within the expected standard for goats.

Guido et al. (2008) and Nava-Trujillo et al. (2010) state that the use of eCG stimulates the onset and timing of estrus in goats, and that increasing the concentration of this gonadotropin predisposes the goats to early onset of estrus. This was not observed in the present study because the groups had a range to the start of equivalent estrus, even with a difference of $70 \%$ in eCG dose between T1 (300 IU) and the other treatments (T2 and T3). Thus, one may suggest that the dose of 30\% (90 IU) applied to the Hou Hai acupoint and the false acupoint was enough to stimulate early and synchronized estrus in goats. Salles et al. (1999) used crossbred Alpina, Moxotó, and Anglo-Nubian goat breeds, with reduced eCG dose (125 IU) administered via vulvar muscular (IVM) and IM protocols with 60 mg of MAP for 11 days and a PGF2 $\alpha$ dose of $50 \mu \mathrm{g}$ via IM, and observed onset of estrus with sponge removal at 48 and $34 \mathrm{~h}$ for the IVM and IM routes, respectively.

However, the range of dispersion was large in $\mathrm{T} 2$ animals for the onset of estrus after sponge removal, as indicated by the high amplitude of the interquartile $39 \mathrm{~h}$. Occurrence of estrus in the range of 24-72 $\mathrm{h}$ after the use of hormonal protocols is considered acceptable when performing estrus synchronization in breeding goats station; however, owing to this dispersion, use of the acupoint Hou Hai in IATF programs is not recommended (CRUZ et al., 2010).

Souza et al. (2011) observed the end of estrus in goats at $70.9 \mathrm{~h}$ after sponge removal treatment for 10 days using $60 \mathrm{mg}$ MAP, $100 \mathrm{IU}$ eCG every $10 \mathrm{~kg}$ of weight, and $37.5 \mu \mathrm{g}$ PGF2 $\alpha$, with slightly longer duration compared to the average of 59.80 $\mathrm{h}$ in the groups. Owing to the higher range for the onset of estrus $(45 \mathrm{~h})$, these authors obtained an estrus duration (ED) of $25.5 \mathrm{~h}$, similar to that found in this experiment $(24.71 \mathrm{~h})$.

Fonseca et al. (2005b) observed respective averages of $33.7 \pm 13.6 \mathrm{~h}$ and $26.7 \pm 10.0 \mathrm{~h}$ of ED in Toggenburg goats using for 6 days of $60 \mathrm{mg}$ MAP, and $22.5 \mu \mathrm{g}$ PGF2 $\alpha$ intramuscularly or in the lateral-vulvar region, and $200 \mathrm{IU}$ of eCG on the fifth day. Moreover, Pietroski et al. (2013), reported averages with similar ED; $28.5 \mathrm{~h}, 21.6 \mathrm{~h}$ and $25.2 \mathrm{~h}$ for protocols lasting 6,9, and 12 days, respectively, with $60 \mathrm{mg}$ of MAP, plus $37.5 \mu \mathrm{g}$ of PGF $2 \alpha$, and $200 \mathrm{IU}$ eCG, both applied to the lateral-vulvar region, and a subsequent dose of hCG 5 days after $\mathrm{AI}$ or natural service.

The duration of estrus (ED) in synchronization protocols in subject to the direct influence of initial and final intervals of estrus at the end of hormonal treatment. Vitaliano et al. (2012) report that many factors can interfere with $\mathrm{ED}$, including penile intrusions at the time of copulation, recurring contact with the player, or the ruffian reducing its duration. In the present study we adopted the natural mating, but this factor did not affect the underweight goats, and elicited no difference between groups.

Gestation rates $(\mathrm{GR} \%)$ at 30 and 60 days did not differ between treatments $(\mathrm{p}>0.05)$ (Table 2). Fonseca and Bruschi (2005) state that the gestation 
rate (GR) in goats may vary between $50-80 \%$ with natural mating (NM) or AI. The results of Pietroski et al. (2013) agreed with that report GR differed when using $\mathrm{NM}$ or $\mathrm{AI}$, varying from 60,50 and
$80 \%$ by treatment with $60 \mathrm{mg}$ of MAP for 6,9 or 12 days, plus $37.5 \mu \mathrm{g}$ of PGF $2 \alpha$ and 200 IU eCG, both administered in the lateral-vulvar region.

Table 2. Rates of gestation and prolificacy of goats subjected to synchronization protocols with hormonal applications acupoint Hou Hai.

\begin{tabular}{lcccc}
\hline Variables & T1 & T2 & T3 & Mean \\
\hline GR 30 days (\%) & 74.0 & 70.6 & 85.7 & 77.0 \\
GR 60 days (\%) & 81.2 & 72.7 & 75.0 & 76.7 \\
Prolificacy (n) & $1.92 \pm 0.90$ & $1.50 \pm 0.55$ & $2.09 \pm 0.54$ & $1.90 \pm 0.72$ \\
\hline
\end{tabular}

T1 - Treatment 1 (100\% IM); T2 - Treatment 2 (30\% acupoint Hou Hai); T3 - Treatment 3 (30\% false acupoint). GR - gestation rate $(\mathrm{p}>0.05)$. There was no statistical difference between treatments for the variables evaluated $(\mathrm{p}>0.05)$.

Maffili et al. (2006) report that the onset of estrus at $37 \mathrm{~h}$ after the device removal did not affect the fertility of goats, confirming the result of the present study, with a total of $35.90 \pm 14.37 \mathrm{~h}$ SRIOE and the GR (\%) average at 30 and 60 days being $77 \%$ and $76.7 \%$, respectively. This demonstrated that estrus induction of the estrus with acupoint Hou Hai resulted in GR (\%) similar to that with $\mathrm{T} 1$ and T3, which used the IM route (Table 2), and as expected for caprine species.

TG after 60 days was added to the experimental period only in 2014, for the purpose of pregnancy confirmation and fetal loss, which was observed in one goat G3. Fonseca et al. (2005a) and Siqueira et al. (2009) also adopted this procedure in two (35 and 70 days) to three (21, 30 and 60 days) assessments to confirm pregnancy and report luteal dysfunction as a cause for early fetal loss in goats, owing to the insufficient synthesis and release of progesterone.

There was no difference in prolificacy between groups $(\mathrm{p}>0.05)$, with an overall average rate of $1.90 \pm 0.72$ kids born (Table 2). The average rate of $1.90 \pm 0.72$ goats born was above the standard average for goats, and according to Simplício (2008), prolificacy in Anglonubian goats may vary from 1.44 to 1.76 .

Araújo et al. (2012) obtained the prolificacy of $1.62 \pm 0.9$ and $1.12 \pm 0.9$ in goats with applications at acupoint Bai Hui and a false acupoint, respectively, using hormonal protocols with duration and doses similar to those used in this study, and they considered these indices to be within the standard for the species. Similar to this study, Maia Júnior et al. (2009) observed prolificacy of 1.83 goats using MAP associated with eCG.

Prolificacy can be influenced by many factors including the race, birth order, power and weight of the mother during pregnancy, coverage, and health, among others. Review signals the genetic gain in selection of animals, the annual population growth in terms of herd productivity, and the herd fertility level through the number of hatched products by deliveries every breeding season (SILVA; ARAÚJO, 2000; SARMENTO et al., 2010).

Synchronization protocols that use reduced and effective hormone doses would provide a reduction in the cost of breeding and consequently, the production system stations, would encourage the adoption of other reproductive biotechnologies with repercussions for the genetic improvement of livestock. They would also make it possible to adjust production according to food availability and the condition of the property. Synchronization of a greater number of females per season is possible due to the financial viability of using biotechnology. Therefore, any investment used in the herd should 
be calculated, and be included in the amount of the final product to be sold (CARNEIRO, 2008).

The use of $37.5 \mu \mathrm{g}$ PGF $2 \alpha$ and 90 IU eCG applied at the acupoint Hou Hai or false acupoint was efficient for estrus synchronization in goats based on the pregnancy rate and prolificacy of animals, in addition to lowering the cost of the protocol. However, it is suggested to consider the practicality of using the false acupoint, using even lower hormone doses, because application of subdoses at the acupoint did not influence the results.

The protocol regarding the handling of animals was approved by the Ethics Committee on Animal Use(CEUA) ofUFRB, process 23007.003079/201470 .

\section{References}

ALTMAN, S. Técnica de instrumentação. In: SCHOEN, A. M. (Ed.). Acupuntura veterinária: da arte antiga à moderna. 7. ed. São Paulo: ROCA, 2006. p. 91-108.

ARAÚJO, M. L.; BARBOSA, L. P.; SOUZA, D. O.; BISCARDE, C. E. A.; ROMERO, D. C. M.; DUTRA, P. A.; SOUZA, R. S.; RIBEIRO, M. O. Custo, taxa de gestação e prolificidade de cabras submetidas a protocolos de sincronização com aplicação hormonal no acuponto Bai Hui. In: REUNIÃO ANUAL DA SOCIEDADE BRASILEIRA DE ZOOTECNIA, 49., 2012, Brasília. Anais... Brasília: Sociedade Brasileira de Zootecnia, 2012. p. 1-3.

CARNEIRO, G. F. Biotécnicas da reprodução assistida em pequenos ruminantes. Tecnologia e Ciência Agropecuária, João Pessoa, v. 2, n. 3, p. 23-28, 2008.

CHAN, W. W.; CHEN, K. Y.; LIU, H.; WU, L. S.; LIN, J. H. Acupuncture for general veterinary practice. Journal of Veterinary Medical Science, Tokyo, v. 63, n. 10, p. 1057-1062, 2001.

CHANG, R.; CHUNG, P. H.; ROSENWAKS, Z. Role of acupuncture in the treatment of female infertility. Fertility and Sterility, Nova York, v. 78, n. 6, p. 11491153, 2002.

CRUZ, M. H. C.; CRUZ, J. F.; MOURA, L. C. O.; TEIXEIRA NETO, M. R.; FERRAZ, R. C. N.; BECKERSILVA, S. C.; SNOECK, P. P. N. Eficácia de implantes de Norgestomet reutilizados no controle do ciclo estral de Cabras leiteiras. Revista Brasileira de Medicina Veterinária, Rio de Janeiro, v. 32, n. 4, p. 219-224, 2010.

FONSECA, J. F. da; TORRES, C. A. A.; MAFFILI, V. V.; BORGES, A. M.; ESPESCHIT, C. J. B.; BALBINOT, P. Z.; OLIVEIRA, R. F. M.; LEITE, P. A. G. Desempenho reprodutivo de cabras Alpinas tratadas com hCG cinco dias após o acasalamento. Revista Brasileira de Zootecnia, Viçosa, MG, v. 34, n. 2, p. 508-513, 2005 a.

FONSECA, J. F.; BRUSCHI, J. H. Reprodução assistida em pequenos ruminantes. Revista de Ciências Agrárias, Belém, n. 43, p. 5-13, 2005. Suplemento.

FONSECA, J. F.; BRUSCHI, J. H.; SANTOS, I. C. C.; VIANA, J. H. M.; MAGALHÃES, A. C. M. Induction of estrus in non-lactating dairy goats with different estrous synchrony protocols. Animal Reproduction Science, Amsterdam, v. 85, n. 1-2, p. 117-124, 2005b.

FONSECA, J. F.; TORRES, C. A. A.; MAFFILI, V. V.; PROSPERI, C. P.; SANTOS, A. D. F.; BORGES, A. M.; RODRIGUES, M. T.; GONÇALVES, A. L.; BALBINOT, P. Z.; ROVAY, H.; RUBERT, M. Indução hormonal de estro em cabras nulíparas na estação de anestro. Revista Brasileira de Reprodução Animal, Belo Horizonte, v. 27, n. 3, p. 528-530, 2003.

GUIDO, S. I.; GUIDO, F. C. L.; NASCIMENTO FILHO, E. V.; FREITAS NETO, L. M.; ALVES, J. D. R.; EVÊNCIO NETO, J.; LIMA, P. F.; OLIVEIRA, M. A. L. Avaliação de protocolos hormonais para inseminar cabras em tempo fixo. Medicina Veterinária, Recife, v. 2, n. 3, p. 13-18, 2008.

HWANG, Y. C.; LIMEHOUSE, J. B. Atlas de acupuntura canina. In: SCHOEN, A. M. (Ed.). Acupuntura veterinária: da arte antiga à moderna. 7 . ed. São Paulo: ROCA, 2006, p. 122-146.

KOMATSU, S.; SAITO, S.; EGAWA, D. Research of acupuncture point (Hou Hai) in bovine on the index value of reproductive efficiency and puncture method. The Tohoku Jornal Veterinary Clinics, Morioka, v. 21, n. 1, p. 1-5, 1998.

LEITE, P. A. G.; CARVALHO, G. R.; RODRIGUES, M. T.; RUAS, J. R. M.; AMORIM, E. A. M.; MAFFILI, V. V. Indução da ovulação em cabras, fora da estação reprodutiva, com LH e GnRH e com estro induzido por progestágenos. Arquivo Brasileiro de Medicina Veterinária e Zootecnia, Belo Horizonte, v. 58, n. 3, p. 360-366, 2006.

LIN, J. H.; CHAN, W. W.; WU, L. S. Acupuntura para tratar distúrbios reprodutivos. In: SCHOEN, A. M. (Ed.). Acupuntura veterinária: da arte antiga à moderna. 7. ed. São Paulo: ROCA, 2006. p. 258-264. 
MAFFILI, V. V.; TORRES, C. A. A.; BRUSCHI, J. H.; FONSECA, J. F.; VIANA, J. H. M. Indução de estro em cabras da raça Toggenburg com dois diferentes dispositivos intravaginais. Arquivo Brasileiro de Medicina Veterinária e Zootecnia, Belo Horizonte, v. 58, n. 3, p. 367-372, 2006.

MAIA JÚNIOR, A.; ARAÚJO, A. A. de; SALLES, M. G. F. Indução e sincronização do estro e da ovulação em cabras leiteiras saanen com uso de dispositivos vaginais associados ou não à $\mathrm{eCG}$ ou efeito macho. Acta Veterinaria Brasilica, Mossoró, v. 3, n. 4, p. 157-162, 2009.

MAIA, K. M.; BEZERRA, A. C. D. S. Controle do ciclo estral em caprinos: revisão. Acta Veterinaria Brasilica, Mossoró, v. 4, p. S14-S19, 2010. Suplemento.

NAVA-TRUJILLO, H.; CHANGO-VILLASMIL, J.; FINOL-PARRA， G.; TORRES-RODRÍGUEZ, P.; CARRILLO-FERNÁNDEZ, F.; MALDONADOSUÁREZ, J.; GIL-HUERTA, L.; AKOURKI, A. Efecto de la dosis de eCG sobre la inducción del celo en cabras mestizas luego de un tratamiento corto con Medroxiprogesterona. Revista Cientifica, Maracaibo, v. 20, n. 2, p. 181-183, 2010.

PAULUS, W. E.; ZHANG, M.; STREHLER, E.; ELDANASOURI, I.; STERZIK, K. Influence of acupuncture on the pregnancy rate in patients who undergo assisted reproduction therapy. Fertility and Sterility, Nova York, v. 77, n. 4, p. 721-724, 2002.

PIETROSKI, A. C. C. A.; BRANDÃO, F. Z.; SOUZA, J. M. G. de; FONSECA, J. F. da. Short, medium or long-term hormonal treatments for induction of synchronized estrus and ovulation in Saanen goats during the nonbreeding season. Revista Brasileira de Zootecnia, Viçosa, MG, v. 42, n. 3, p. 168-173, 2013.

QUICK, F. S. de S. Comparação da indução de estro pelo método convencional e aplicação de $10 \%$ da dose de prostaglandina e eCG em pontos de acupuntura em ovelhas da raça Santa Inês. 2010. Monografia (Especialização em Acupuntura Veterinária) - Instituto Jacqueline Peker, Belo Horizonte.
SALLES, H. O.; ANDRIOLI, A.; MOURA SOBRINHO, P. A.; SOARES, A. T.; MORAES, J. B.; MARQUES, M. A. J. Doses e vias de aplicação da gonadotrofina coriônica equina (eCG) para sincronização do estro em caprinos. Ars Veterinária, Jaboticabal, v. 15, n. 2, p. 84-88, 1999.

SARMENTO, J. L. R.; PIMENTA FILHO, E. C.; ABREU, U. G. P. de; RIBEIRO, M. N.; SOUSA, J. E. R. de. Prolificidade de caprinos mestiços leiteiros no semiárido nordestino. Revista Brasileira de Zootecnia, Viçosa, MG, v. 39, n. 7, p. 1471-1476, 2010.

SILVA, F. L. R.; ARAÚJO, A. M. Desempenho produtivo em caprinos mestiços no semi-árido do Nordeste do Brasil. Revista Brasileira de Zootecnia, Viçosa, MG, v. 29, n. 4, p. 1028-1035, 2000.

SIMPLÍCIO, A. A. Estratégias de manejo reprodutivo como ferramenta para prolongar o período de oferta de carnes caprina e ovina no Brasil. Tecnologia e Ciência Agropecuária, João Pessoa, v. 2, n. 3, p. 29-39, 2008.

SIQUEIRA, A. P.; FONSECA, J. F.; SILVA FILHO, J. M.; BRUSCHI, J. H.; VIANA, J. H. M.; PALHARES, M. S.; BRUSCHI, M. C. M.; PEIXOTO, M. P. Reproductive parameters of Toggenburg goats inseminated with cooled semen diluted in egg yolk extender. Arquivo Brasileiro de Medicina Veterinária e Zootecnia, Belo Horizonte, v. 61, n. 2, p. 299-305, 2009.

SOUZA, R. S.; BARBOSA, L. P.; AGUIAR, C. S.; FIGUEREDO JÚNIOR, J.; RIBEIRO, M. O.; MENDES, C. S.; ALMEIDA, V. F.; ARAÚJO, R. C. S. A.; PINHEIRO, A. M.; MARQUES, J. A. Sincronização da ovulação utilizando FSH em substituição à eCG em cabras. Arquivo Brasileiro de Medicina Veterinária e Zootecnia, Belo Horizonte, v. 63, n. 3, p. 753-756, 2011.

TRALDI, A. de S.; LOUREIRO, M. F. P.; CAPEZZUTO, A.; MAZORRA, A. L. Métodos de controle da atividade reprodutiva em caprinos. Revista Brasileira de Reprodução Animal, Belo Horizonte, v. 31, n. 2, p. 254260, 2007.

VITALIANO, A. B.; SALlES, M. G. F.; VIANA NETO, A.; RODRIGUES, I. C. S.; ARAÚJO, A. A. de. Comportamento reprodutivo caprino e ovino, utilizando o efeito macho interespécie. Revista Acadêmica: Ciências Agrárias e Ambientais, Curitiba, v. 10, n. 3, p. 221-228, 2012. 